\title{
Geological and geotechnical characterisation of the Khotila landslide in the Dharchula region, NE Kumaun Himalaya
}

\author{
Ambar Solanki ${ }^{1}$, Vikram Gupta ${ }^{1, *}$, S S Bhakuni $^{1}$, Pratap Ram $^{1}$ \\ and MALliCKARJun JOSHI ${ }^{2}$ \\ ${ }^{1}$ Wadia Institute of Himalayan Geology, 33 General Mahadeo Singh Road, Dehradun 248 001, Uttarakhand, India. \\ ${ }^{2}$ Department of Geology, Banaras Hindu University, Varanasi, India. \\ ${ }^{*}$ Corresponding author.e-mail: vgupta_wihg@yahoo.com
}

MS received 18 April 2018; revised 6 August 2018; accepted 21 August 2018; published online 22 March 2019

On 04 October 2016, a severe landslide had occurred in the vicinity of Khotila village in Dharchula, region of NE Kumaun Himalaya. This landslide may be classified as typical rockslide, involving thin veneer of debris on the slope as well as the highly shattered rockmass. The slide has been divided into three morpho-dynamic zones, viz., (i) Zone of detachment between elevation 1000 and 960 m, (ii) Zone of transportation between elevation 960 and $910 \mathrm{~m}$, and (iii) Zone of accumulation between elevation 910 and $870 \mathrm{~m}$. The landslide had occurred at the end of the monsoon season when the slope was completely saturated. It has been noted that the area received $\sim 88 \%$ rainfall during the monsoon months which is about two times more rainfall during 2016 monsoon than during 2015 monsoon. Geotechnical testing of the soil overlying the rockmass, corroborate the soil as 'soft soil' with compressive strength of $42 \mathrm{kPa}$ and friction angle of $27.4^{\circ}$. Granulometry confirms the soil as having $>97 \%$ sand and silt size particles and $<3 \%$ clay size particles, indicating higher permeability. Mineralogically, the soil dominantly constitutes quartz, muscovite and clinochore. Though no swelling clay minerals has been observed, the higher permeability and low strength of the soil, and concentrated higher rainfall during 2016 are the main causes for the landslide to occur. This landslide has partially blocked the flow of Kali river that serve as a boundary between India and Nepal and is endangering the habitants of the Khotila and Bangabagar villages, situated downstream in the Indian and Nepalese side of the Himalaya. In order to understand the stability of the slope, finite element modelling of the landslide has been carried out that points towards higher concentration of stresses in the landslide zone, indicating that there is further probability for the failure of landslide mass. It is therefore suggested that the landslide must be monitored continuously, particularly during the rainy season and also the risk posed by this landslide must be evaluated so as to avoid any further loss to life and infrastructure in the region.

Keywords. Khotila Landslide; Kali river; rainfall; geotechnical test; finite element method; slope stability.

\section{Introduction}

Landslides and other related mass movement activities are common in the Himalayan Fold-
Thrust belt due to its rugged and complex topography, active tectonics and a wide range of climatic conditions along with heavy and concentrated rainfall during the monsoon periods. 
These may primarily be caused by geological, geomorphical, anthropogenical and geotechnical characteristics of the hill slopes and are defined as the movement of a mass of material en masse down a slope (Cruden 1991). These occur every year during the later part of the monsoon season or immediately after the rainy season and pose a serious threat to the lives and property in the region. A large number of mass movements, e.g., 1998 Malpa rockfall in the Kali valley (Kumar and Satyal 1999; Paul et al. 2000), 1998 Okhimath landslide in the Mandakini valley (Bist and Sah 1999), 1998 Surabhi Resort landslide in Mussoorie township (Gupta and Ahmed 2007), 2001 Budha Kedar landslide in the Balganga valley (Sah et al. 2003), 2003 Varunavat Parvat landslide in the Bhagirathi valley (Gupta and Bist 2004; Sarkar et al. 2011), Kaliasaur landslide in district Rudraprayag (Kimothi et al. 2010; Bisht and Pandey 2016), 2015 Balia Nala landslide in Nainital township (Gupta et al. 2016b) and numerous landslides in the Uttarakhand Himalaya during 2013 Kedarnath disaster (Martha et al. 2015; Allen et al. 2016) are some of the examples of recent landslides that struck in the Garhwal and Kumaun Himalaya causing huge loss of lives and property in the region. It is estimated that after every $2 \mathrm{~km}$, there is a chronic landslide in the Himalayan terrain (Valdiya 1980).

Although triggered mainly by earthquakes or immense rainfall, the landslides in the Himalayan terrain are mainly caused by varying proportions of geological, geomorphological and geotechnical characteristics of slope, including the anthropogenic activities (Hewitt 1988; Bartarya and Valdiya 1989; Choubey et al. 1992; Pachauri and Pant 1992; Gerrard 1994; Bartarya et al. 1996; Panikkar and Subramanyan 1996; Sah and Mazari 1998; Sati et al. 1998; Gupta et al. 1999, 2016b; Rautela and Thakur 1999; Naithani et al. 2002; Saha et al. 2002; Gupta and Bist 2004; Neaupane and Achet 2004; Pant and Khayingshing 2005; Owen et al. 2008; Anbalagan et al. 2008; Dahal et al. 2009; Anbarasu et al. 2010; Kanungo et al. 2013; Sharma and Singh 2013; Kumar et al. 2014; Jamir et al. 2017). As no two landslides are identical in their causes and triggering factors, it is therefore imperative to study each and every landslide to plan for its mitigation measures and strategies for the further development of the area.

It has been reported in the past that landslides across the international borders have caused enormous loss to the Indian sub-continent, e.g., a landslide in 2000 along the path of the Satluj river in the Tibetan Plateau has caused huge loss of lives and property in the Kinnaur and Shimla districts of Himachal Pradesh and again in 2003, a small landslide along the path of the Pareechu Nala, a tributary of river Spiti in the Tibetan Plateau has caused huge devastation in the Kinnaur district of Himachal Pradesh (Gupta and Sah 2008). Both these events have caused a loss in terms of crores of Indian rupees, besides the hardship to the locals, as the area was entirely cut-off from the rest of the country for more than 4 months (Gupta and Sah 2008).

The Kumaun Himalaya located in the eastern part of Uttarakhand state shares its borders with Nepal having Kali river as the international boundary. Numerous landslides have known to occur in the upper part of the Kali river posing a serious threat to the villages and infrastructures of both the countries located along both the sides of the river. Many of these landslides go unnoticed and unreported and only landslides posing a threat to the human habitation are being reported and studied. One example of such catastrophic landslide that occurred in the area is the Malpa landslide that occurred in the upper part of the Kali river in August 1998, has killed about 220 people including 60 pilgrims en route to Kailash-Mansarovar in Tibet (Paul et al. 2000).

During October 2016, a severe landslide had occurred on the SE facing slope on the right flank of the Kali river near Khotila village. It is endangering the local habitants of the village and also the habitants of Bangabagar village located in Nepal opposite to the landslide face. The exact causes for the occurrence of this landslide are unknown. Although the total annual rainfall during the year 2016 was normal, the area received higher and concentrated rainfall during the preceding months of the occurrence of the landslide. In order to understand the causes and the triggering factors for this landslide, detailed surface geological, mineralogical and geotechnical characteristics of the slope along with the analysis of daily rainfall data have been carried out. Further, modelling of the slope exhibiting the landslide has also been done to understand its possible failure conditions in the future.

\section{Study area}

The study area is located at longitude $80^{\circ} 33^{\prime} 00^{\prime \prime} \mathrm{E}$ and latitude $29^{\circ} 51^{\prime} 00^{\prime} \mathrm{N}$ and lies in the 


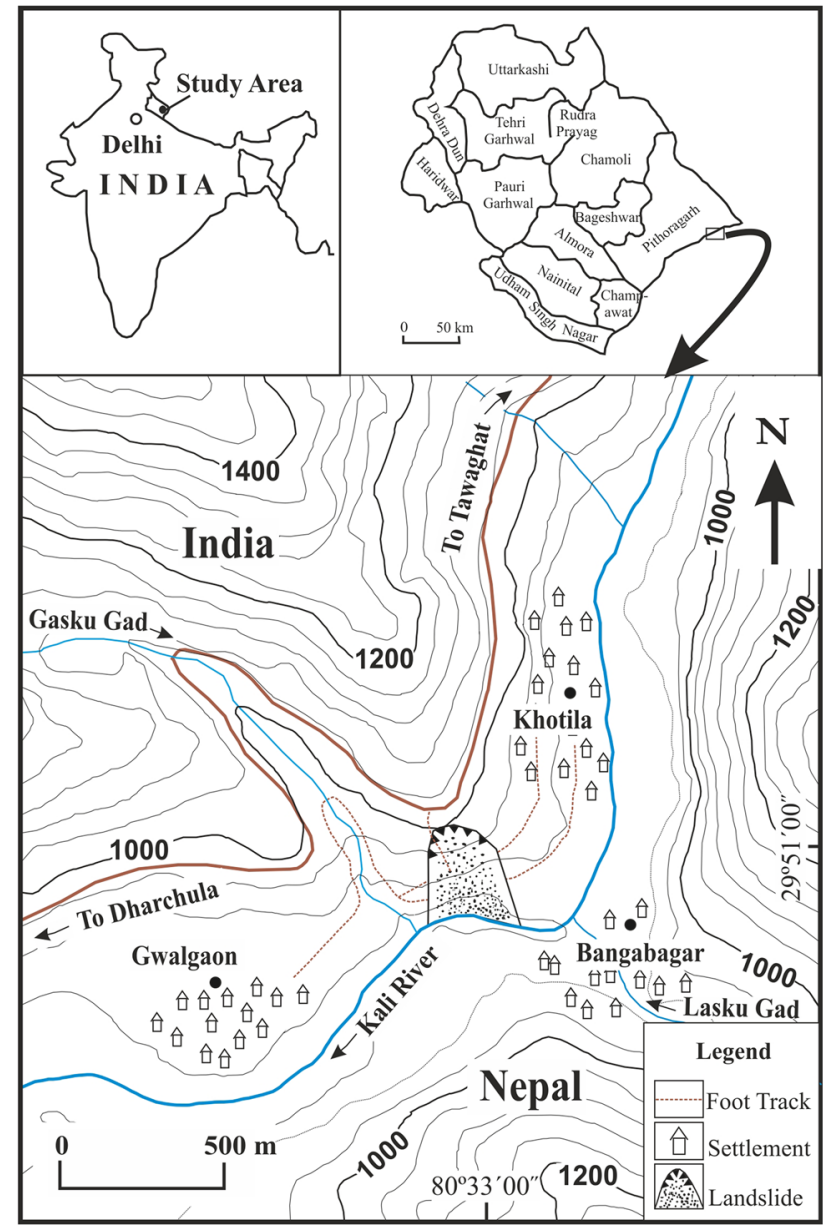

Figure 1. Location map of the Khotila landslide.

Pithoragarh district of the Kumaun Himalaya. It is located on the right bank of the Kali river that flows at an elevation of $\sim 870 \mathrm{~m}$ above msl in the study area. In the vicinity of the landslide, Khotila village is located on the eastern facing slope on the right bank of the Kali river in the Indian part of the Himalaya, whereas Bangabagar village is located on the left flank of the Kali river on the Napalese side of the Himalaya on the north-facing slope (figure 1).

The crown of the landslide is located at an elevation of $\sim 1000 \mathrm{~m}$. The road connecting Pithoragarh with Tawaghat runs at an elevation of $\sim 1020 \mathrm{~m}$ above msl above the crown region of the landslide (figure 1). A seasonal stream 'Gasku Gad' situated on the right flank of the landslide, flows from NW to SE and joins the Kali river near the right flank of the landslide whereas 'Lasku Gad' flowing from Nepal joins the Kali river on the left flank.

\section{Physiographic setting}

Geologically, the study area and its environs constitute the rocks belonging to the Mandhali Formation of the Lesser Himalaya (Valdiya 1980). The dominant country rocks are dolomitic limestone, calcareous slates with subordinate variegated shales and pyritic phyllites. These rocks are highly folded, faulted, jointed and fractured. These rocks are overlain by the rocks of the Berinag Formation along Berinag Thrust having quartzites as the dominant rock type, and the Chipplakote Crystallines along the Chipplakote Thrust consisting dominantly of schist and gneiss. The rocks of the Mandhali Formation are underlain by the Deoban Formation consisting dominantly of limestone and carbonaceous slates. Further, to the south of the Deoban Formation lies the Rautgara Formation consisting dominantly of fine- to medium-grained muddy quartzite and slates (figure 2).

In the vicinity of the crown of the landslide, the Mandhali Formation consisting of thinly foliated slate with thin bands of black shales along with thin laminated carbonaceous silty layers trending E-W and dipping $32^{\circ}$ towards north are exposed (figure 3a). Whereas, near Dharchula, in the Kali river section, $\mathrm{E}-\mathrm{W}$ trending slates dipping steeply at an angle of $80-85^{\circ}$ towards the south are exposed (figure $3 \mathrm{~b}$ ). This sudden change in the attitude of beds, along with highly crushed rocks along the Lasku Gad (figure 3c) might be due to E-W trending fault hereafter called 'Lasku Gad Fault'. The rocks along the Lasku Gad in Nepal Himalaya, opposite the Khotila landslide, are characterised by the presence of a large number of outcropscale faults and shear zones (figure 3c). Other major faults present in the vicinity of landslide and its adjacent areas are the Dharchula Fault and Ghatibagar-Kalika Fault (Valdiya 1980).

Geomorphologically, the landslide is located at the base of an NW-SE trending spur that descends to the Kali river. The landslide forms a triangular facet at the base of this spur (figure 4). The southern side of the spur is flanked and drained by the Gasku Gad. Further, the area is highly rugged with steep slopes, narrow valleys and high mountains. The slopes, in general, are steep of the order of $60-70^{\circ}$. The relief in the area is $1038 \mathrm{~m}$ with a river flowing at $\sim 870 \mathrm{~m}$ and the top of the mountain is at $1908 \mathrm{~m}$ above msl.

The area experiences hot and humid to subhumid climate with the maximum temperature reaching to $\sim 45^{\circ} \mathrm{C}$. The winters, in general, are 


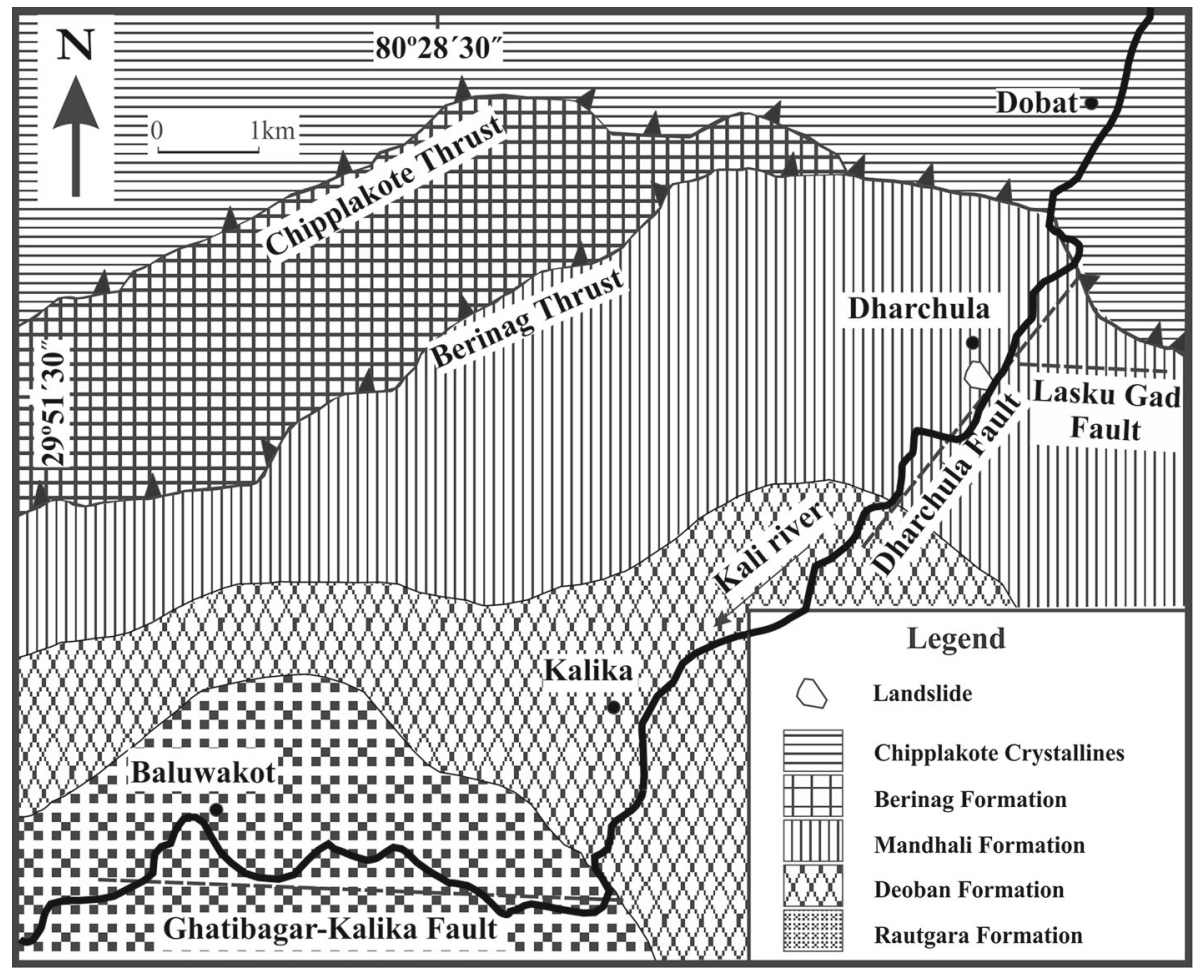

Figure 2. Regional geological map of the Khotila landslide area and its environs (modified after Valdiya 1980; Paul 1985).
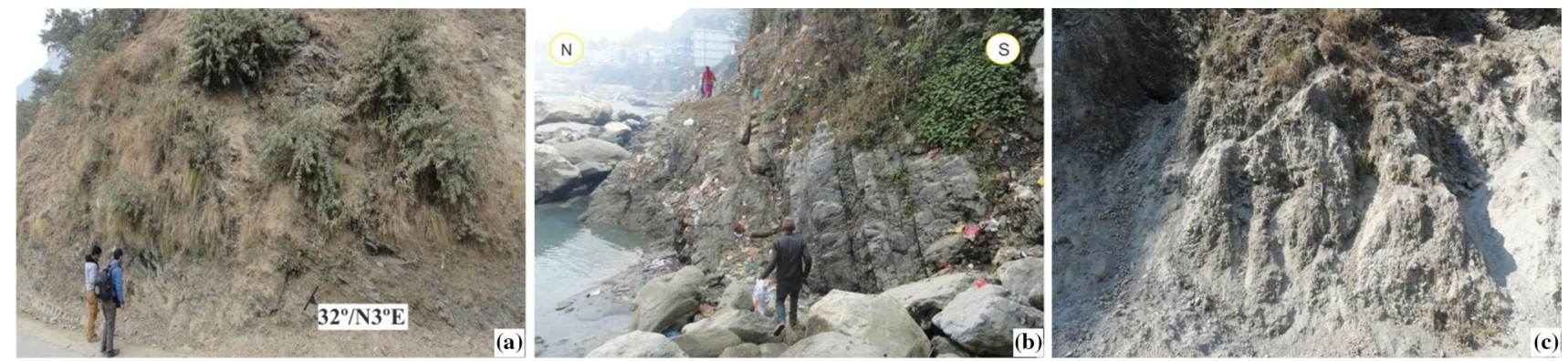

Figure 3. (a) View of the crown portion of the landslide exhibiting thinly foliated slate dipping towards north at moderate angle of $\sim 30^{\circ}$, (b) view of the E-W trending rocks at Dharchula, dipping at steep angle of $\sim 70^{\circ}$ towards south and (c) close view of the shear zone located along the Lasku Gad.

cold with an average minimum temperature of $\sim-3^{\circ} \mathrm{C}$. Daily rainfall during $2011-2016$ suggests that the total average annual rainfall in the area is $\sim 2400 \mathrm{~mm}$ with $\sim 85 \%$ rains fall during monsoon months between June and September (figure 5a). Prior to 4 October 2016, the date of occurrence of landslide, the area recorded rainfall of 493, 901, 487 and $283 \mathrm{~mm}$ during 29 days in June, 31 days in July, 27 days in August and 23 days in September, respectively, cf. 212, 322, 398 and $181 \mathrm{~mm}$ rainfall in June, July, August and September months of 2015 (figure 5b).

\section{Characteristics of the Khotila landslide}

The Khotila landslide is a typical rockslide on the southeast facing slope covered with a thin veneer of debris material. The material involved in the sliding process is mostly pebbles and boulders of dolomitic limestone and slates in a mixture of sand-silt-clay along with the thin debris cover lying on the slope. The dominant size of the pebble is $5-10 \mathrm{~cm}$ diameter. The scarp of the active landslide is arcuate in shape and is located at an elevation of $\sim 1000 \mathrm{~m}$ above msl. Its width is 


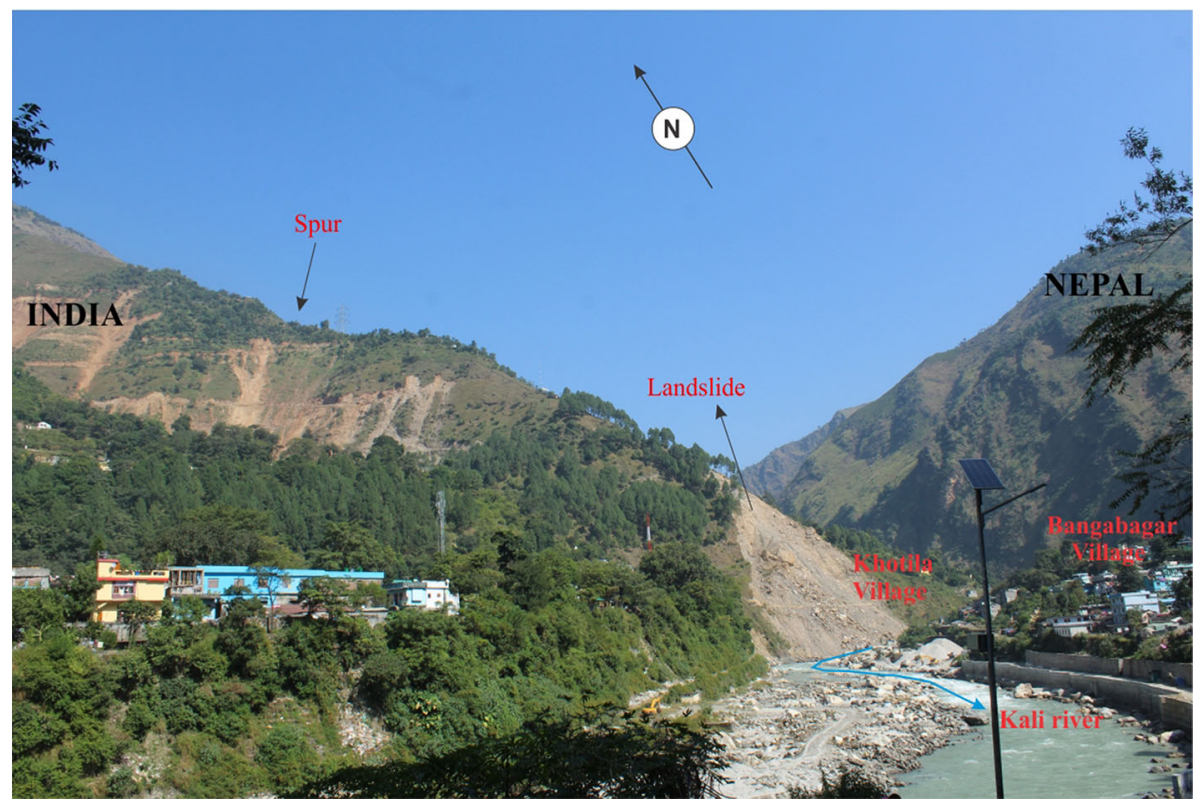

Figure 4. Panoramic view of the Khotila landslide.
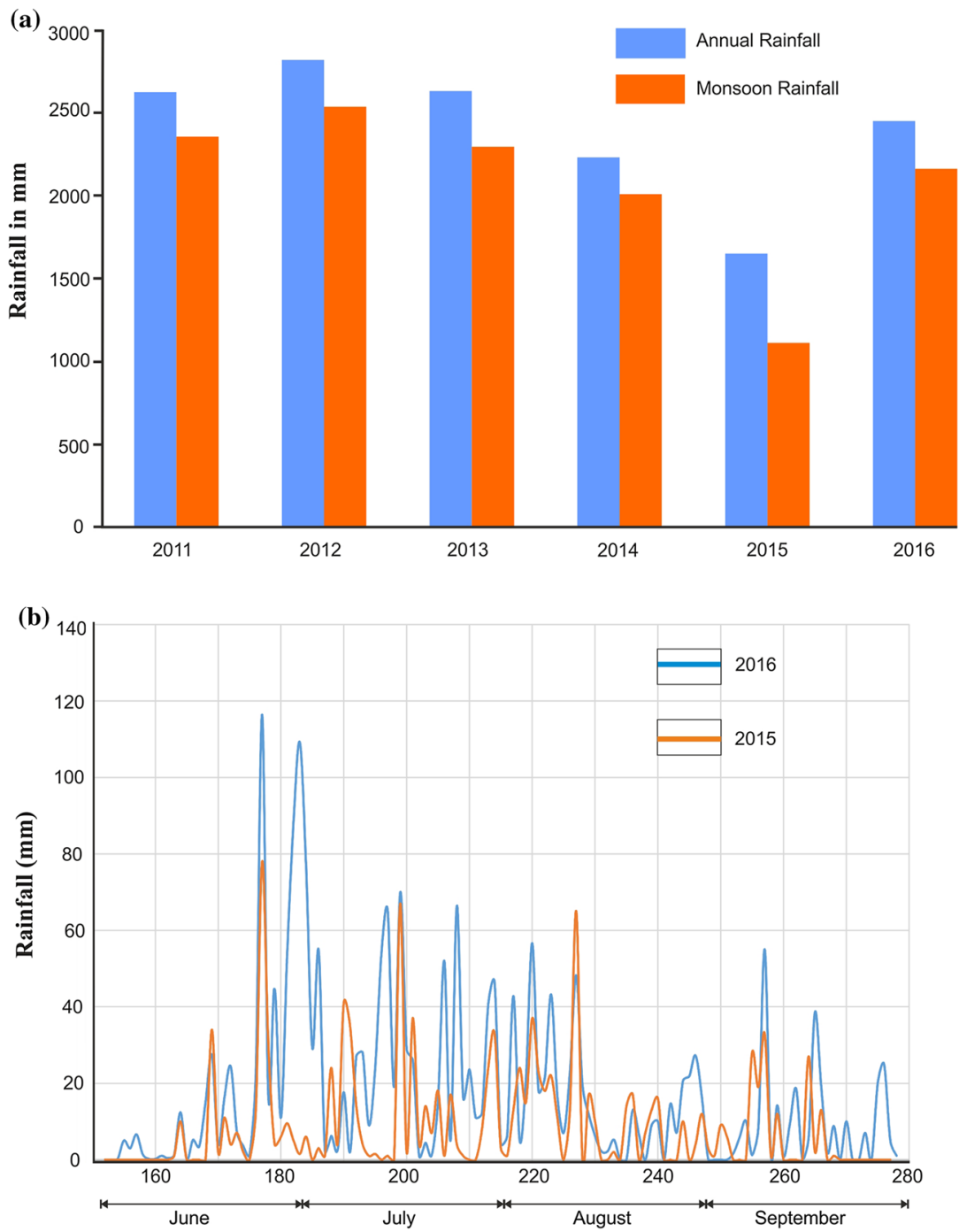

Figure 5. (a) Total annual rainfall during 2011-2016 in the Dharchula area. (b) Line diagram plot of daily rainfall for June, July, August and September for the years 2015 and 2016 clearly depicting higher rainfall during 2016. 


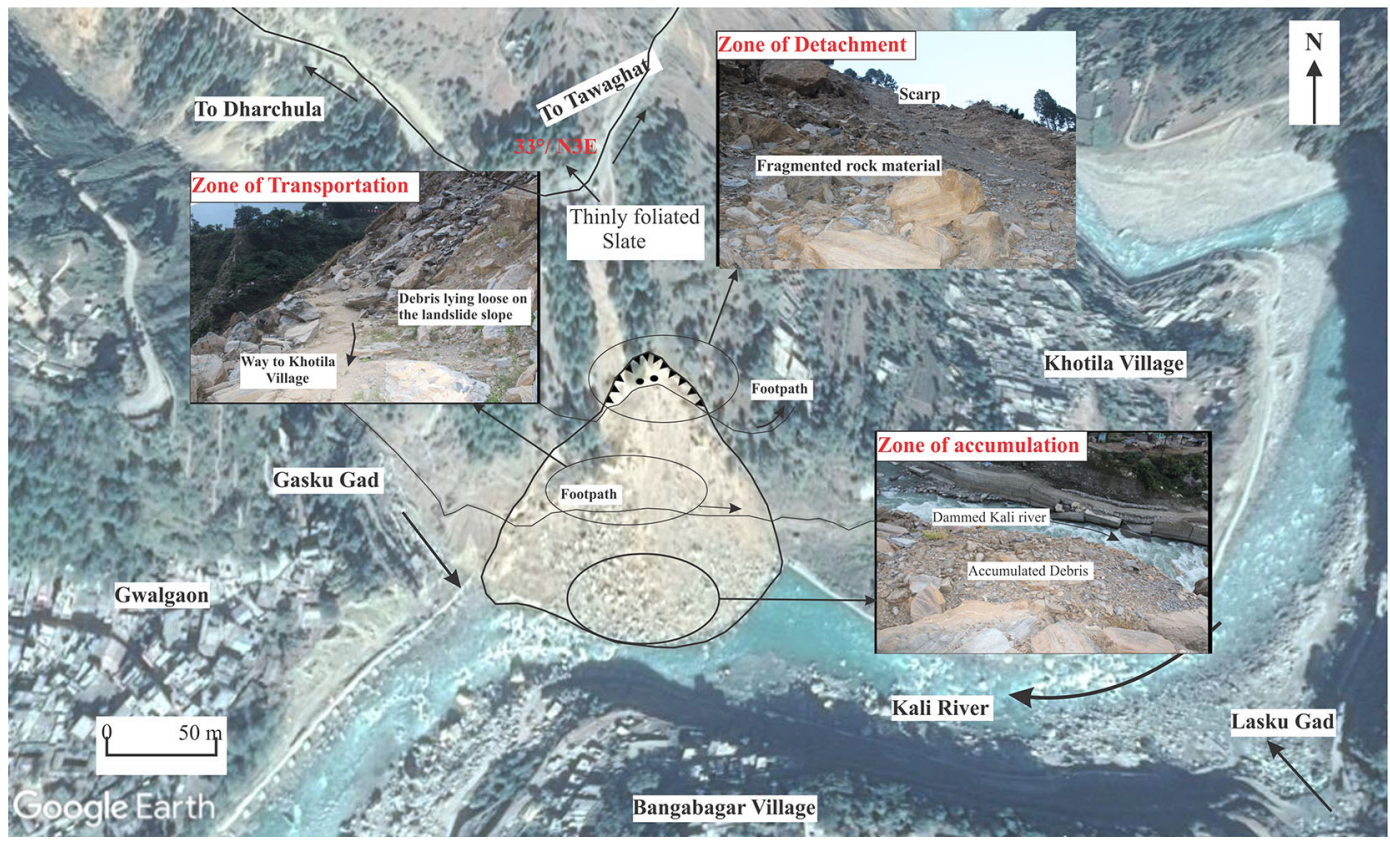

Figure 6. Google Earth image of the Khotila landslide with inset pictures indicating (a) zone of detachment, (b) zone of transportation and (c) zone of accumulation. Black dots represent the location of the soil samples.

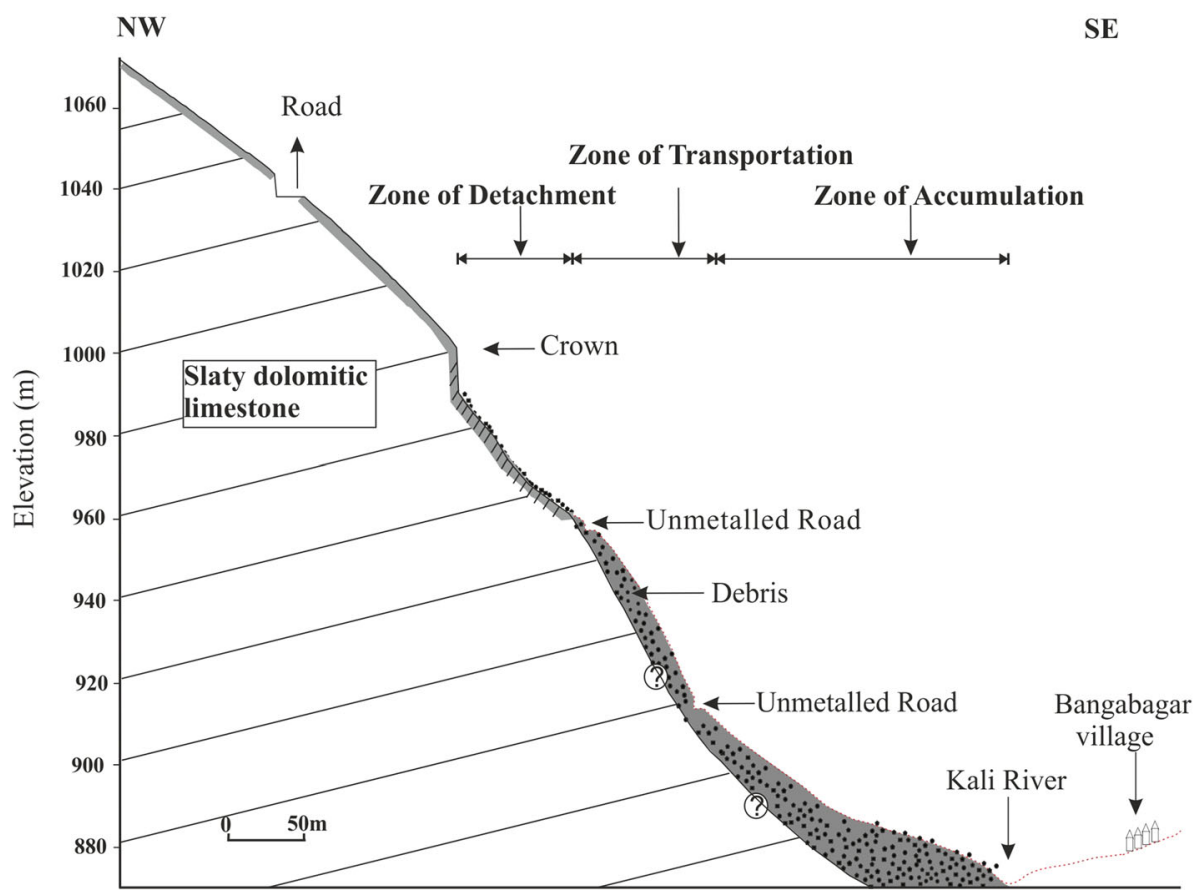

Figure 7. Cross-section of the slope passing through the Khotila landslide depicting (i) zone of detachment, (ii) zone of transportation and (iii) zone of accumulation.

about $10 \mathrm{~m}$ at the top and progressively increases to $\sim 150 \mathrm{~m}$ in the central part of the landslide (figure 6).

In-situ rocks are observed on the right flank of the landslide. These are mainly slates and dolomitic limestones which are highly fissile and weathered. The slide can be divided into three morpho-dynamic zones (figure 7). These are given as follows.

\subsection{Zone of detachment (1000-960 $\mathrm{m}$ above msl)}

The zone of detachment is highly fractured and consists of a crown portion of the slide beyond the 
main scarp and the active scarp itself. It is spoon shaped and is about $400 \mathrm{~m}$ long, $200 \mathrm{~m}$ wide and about $20 \mathrm{~m}$ deep. Approximately $1.25 \times 10^{6} \mathrm{~m}^{3}$ of quaternary material has been displaced and has a total potential of about five to six times the already displaced volume. Some of the material is still lying loose on the slope (figure 6). The slope in this zone varies between $50^{\circ}$ and $60^{\circ}$.

\subsection{Zone of transportation (960-910 $\mathrm{m}$ above $\mathrm{msl}$ )}

The zone of transportation lies immediately below the zone of detachment. It transports the detached material from the main scarp into the river below. All along its track, the material is lying loose on the slope (figure 6) that may eventually find its way downslope. It is slightly convex in shape and the slope angle of the transportation track varies between $50^{\circ}$ and $70^{\circ}$.

\subsection{Zone of accumulation (910-870 $\mathrm{m}$ above $\mathrm{msl}$ )}

The zone of accumulation is the area where the displaced material has accumulated. This zone lies at the bottom and has partially dammed the Kali river (figure 6). The debris from the debris-filled slope as well as from the fractured bedrock has detached from the crown portion, transported and has finally deposited in this zone. It is also the toe portion of the landslide. This zone is generally concave in shape and extends from 910 to $870 \mathrm{~m}$ up to the river bottom.

\section{Geotechnical investigation}

In order to understand the behaviour of the soil and rocks constituting the slope, geotechnical characterisation of soil was carried out in the Wadia Institute of Himalayan Geology, Dehradun. Soil samples were collected from the scarp of the landslide. Sample location is depicted in figure 6 with two black dots. The tests include grain size determination, direct shear, Atterberg Limits (liquid limit and plastic limit) and X-ray diffraction (XRD) analyses. These are briefly described in the following sections.

\subsection{Grain-size analysis}

In order to characterise the geotechnical properties of the material constituting the slip surface, soil samples were collected from the scarp portion of the landslide. The grain-size distribution as per the (a)
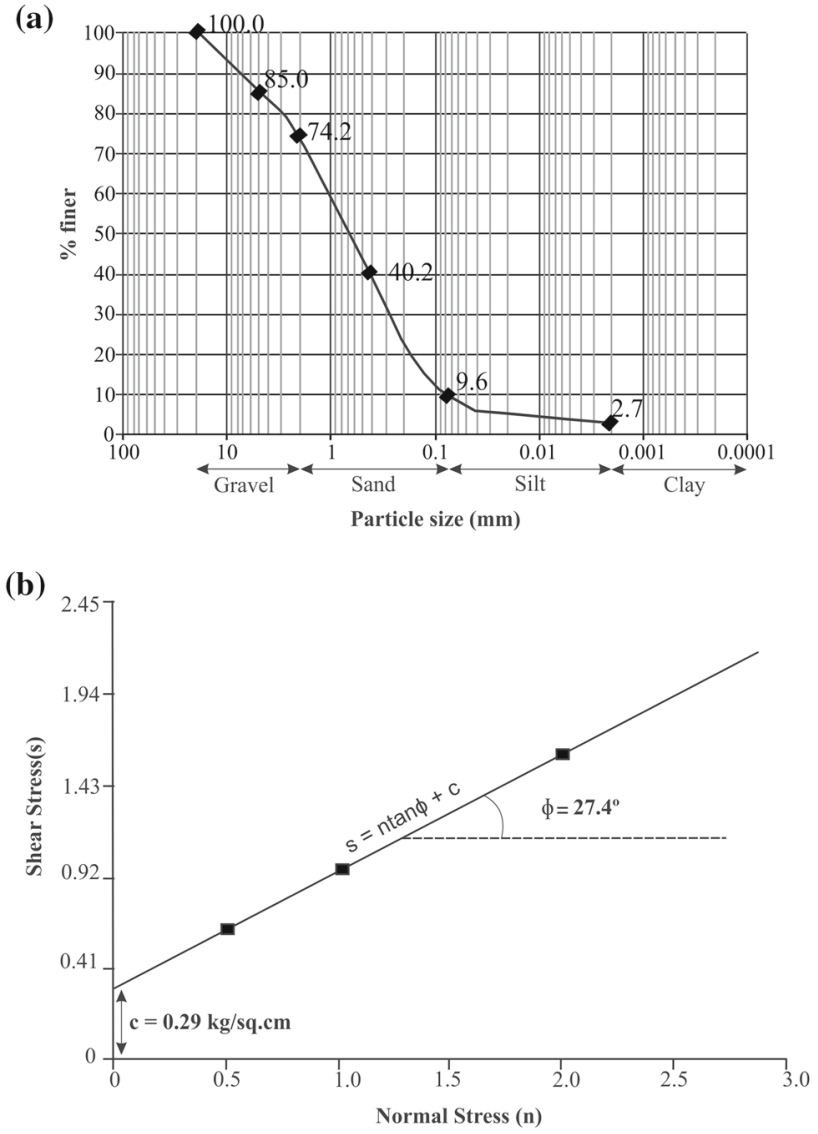

Figure 8. (a) Grain size distribution curve of the slope material constituting the slope of the Khotila landslide, indicating the dominance of the sand-silt size particle and (b) graph showing normal stress vs. shear stress of soil.

Indian standards (IS 2720 (Part 4) 1985a) for the coarser material was determined using standard dry sieving and for the finer material hydrometer method was used. The results indicate that the soil constitutes $15 \%$ gravel, $75.4 \%$ sand and $9.6 \%$ fines, including silt and clay (figure 8a). Hydrometer analysis indicates the dominance of the silt size particles $(>97 \%)$ and with clay content $<3 \%$. The greater part of the soil constitutes $4.75-0.075 \mu \mathrm{m}$ size particles, therefore the soil may be classified as 'Gravelly sand (SP)' (IS: 1498-1970 2007).

\subsection{Direct shear test}

A series of consolidated-undrained direct shear tests were performed on the soils having grains not coarser than $4.75 \mathrm{~mm}$. Tests were conducted in a standard direct shear box apparatus having box dimensions of $120 \times 150 \times 70 \mathrm{~mm}$. The samples were sheared at a constant rate of 0.625 $\mathrm{mm} / \mathrm{min}$ and under constant normal stress of 50 , 100 and $200 \mathrm{kN} / \mathrm{m}^{2}$ (IS: 2720 (Part 13) 1986). The 


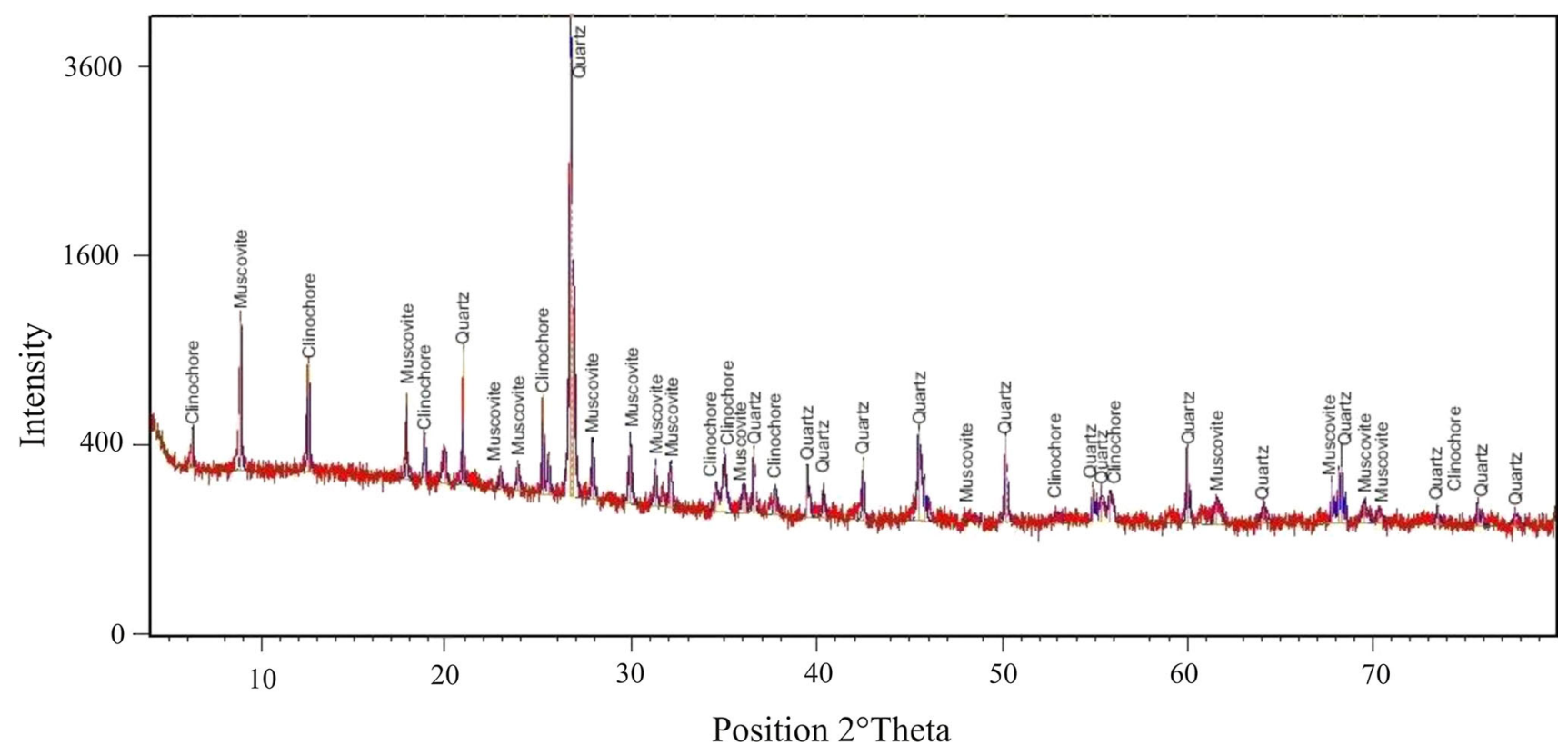

Figure 9. X-ray diffractogram indicating the dominance of quartz, muscovite and clinochore.

value of cohesion $(\boldsymbol{C})$ and the angle of internal friction $(\varphi)$ as deciphered from the failure envelop is $0.29 \mathrm{~kg} / \mathrm{cm}^{2}$ and $27.4^{\circ}$, respectively (figure $8 \mathrm{~b}$ ).

\subsection{Atterberg limits}

Atterberg limits defined by the liquid limit and plastic limit are the amount of water required to be added to solid dry soil so that it behaves like liquid or plastic is termed as liquid limit and plastic limit, respectively. Higher the liquid limit and plastic limit, the greater the tendency to attract water before it fails. These limits were calculated on soil finer than $425 \mu \mathrm{m}$ as per the standard methodology (IS 2720 (Part 5) 1985b). The result indicates that the soil possesses $29.5 \%$ liquid limit and $20.82 \%$ plastic limit, indicates the plasticity index of 8.68 . Therefore, the soil may be classified as 'medium plastic' (Murthy 2002).

\subsection{Unconfined compressive strength (UCS)}

UCS of the soil defines the compressive load per unit area required to fail the cylinder of soil without lateral support. In the present case, cylindrical samples of the soil were prepared having the length to diameter ratio of $2: 1$. Both the ends of the cylindrical cores were made smooth and parallel to each other. The test was performed at a constant strain rate of $1.50 \mathrm{~mm}$ per min (IS 2720 (Part 10) Standard-IS 1991). The test results exhibit the soil having UCS of $42 \mathrm{kPa}$, and accordingly, the soil may be classified as 'soft soil' (Murthy 2002).

\section{Mineralogical and chemical analysis}

In order to characterise the mineralogical and chemical composition of the soil, and also to look for the presence of any swelling clay minerals, XRD and XRF analyses were carried out. XRD of bulk soil sample was carried out using Philip PANalytical XPERT PRO diffractometer. The bulk sample was crushed in the agate mortar and pestle to obtain a fine powder for the slide preparation. The sample slide was scanned at a $2 \theta$ range of $4^{\circ}-79^{\circ}$ with a count of two per step. The XRD data was interpreted using ' $\mathrm{X}$ pert high score plus' software. The XRD test clearly demonstrates the dominance of quartz, muscovite and clinochlore and the absence of any swelling clay minerals, where peaks with the lesser intensity of halloysite, natronite and beidellite are observed (figure 9).

\section{Numerical modelling of the Khotila landslide}

Finite-element method (FEM) is one of the numerical method used widely to solve the slope stability problem having a complex slope configuration. The main advantage of this method is that presumption about slip surface is not required. 
In the present case, FEM was carried out using shear strength reduction (SSR) technique in order to compute the 'safety factor', for the slope of the Khotila landslide. The method directly measures the deformation in terms of strain and displacement. The geometry of slope section was extracted using ALOS PALSAR DEM having $12.5 \mathrm{~m}$ resolution and updated with the field observations. The movement of $X$-axis and $Y$-axis of the slope was kept fixed whereas the slope face and the rock debris interface were kept free for displaying the maximum shear strain and total displacement. The joint pattern was that of the foliation plane (J1) and one joint set (J2) which was included for the modelling (figure 10a). A six nodded mesh was used to discretise the landslide debris and the rock of the slope as it improves the accuracy in SSR approach (Nian et al. 2011) with 3424 elements present in the slope. In the model, $99.2 \%$ of the elements are of good quality. Because the slope is covered with thin veneer of debris material $(<1 \mathrm{~m})$, for the numerical modelling, the input parameters of soil were used for the slope surface material and the rocks were used for the sections beneath the soil cover, as depicted in the cross-section of the landslide (figure 7). Soil parameters used for the modelling, e.g., soil friction angle and cohesion were obtained in the Geotechnical Laboratory of the Wadia Institute and the standard values for the materials were used, e.g., standard Poisson's ratio for gravelly sand was taken as 0.3 (Bowles 1996; Wang et al. 2001). Various parameters for generalised Hoek and Brown failure criteria were calculated using Geological Strength Index system of the rock mass (Cai et al. 2007). The slope material properties for the soil and the rock mass used for the modelling are presented in table 1 . The analysis was performed using Phase $^{2}$ (version 9.0) software of Rocscience.

SSR technique (Zienkiewicz et al. 1977; Matsui and San 1992) allows the systematic use of finiteelement analysis to determine the stress reduction factor (SRF) in which the soil property values keep on reducing till the failure. The strength parameters of a slope are reduced by a certain factor (SRF), and the finite-element stress analysis is computed. The process is repeated for different values of SRF, until the model becomes unstable which determines the critical strength reduction factor (critical SRF) of the slope. Cohesion and friction angle values of the slope material are reduced till failure occurs; it is assumed that the failure mechanism of the slope is directly related to the development of shear strain (Roscoe 1970). The approach is presented in the following equations:

$$
\begin{aligned}
C_{r} & =\frac{C}{\mathrm{SRF}}, \\
\tan (\phi) & =\frac{\tan (\phi)}{\mathrm{SRF}},
\end{aligned}
$$

where $\mathrm{SRF}$ is the strength reduction factor, and $C$ and $\phi$ are original shear strength parameters (cohesion and friction angle).

The SSR approach with a tolerance of 0.01 was applied to the model. The slope material was considered as an elastic-plastic substance by keeping the peak values equal to the residual ones (Griffiths and Lane 1999; Gupta et al. 2016a). The field load was taken as gravity which defines in-situ field stress that varies linearly with the depth in which lithostatic condition is assumed and hence the ratio of vertical to horizontal stress is considered as unity as suggested by Talobre (1967). The results of the FEM analysis on the slope of the Khotila landslide indicate that there is maximum strain and displacement in the zone of transportation sandwiched between two footpaths in the main body of the landslide (figure 10b and c). It is interpreted to be 0.41 and 1.26 , respectively, indicating the further probability of the occurrence of a landslide in the future.

\section{Discussion and conclusions}

There are many incidences of rain triggered landslides in the Himalayan terrain. Many of the devastating landslides occur mainly towards the end of the monsoon season i.e., during August and September or early part of the October, when the slopes are fully saturated. Some of the recent devastating rain-triggered landslides in the Himalaya are summarised in Chang et al. (2008) and Dahal and Hasegawa (2008).

The analysis of daily rainfall data for the landslide area during 2011-2016 depicts variable rainfall during the years and the average annual rainfall in the area reported is about $2400 \mathrm{~mm}$ with $\sim 80 \%$ rains falling during the monsoon months between June and September (figure 5a). Rainfall during the years 2014 and 2015 was observed to be 2189 and $1653 \mathrm{~mm}$ which is below normal and in 2016, although the total annual rainfall was observed to be normal (about $2450 \mathrm{~mm}$ ), most of the rainfall was concentrated in the monsoonal months 

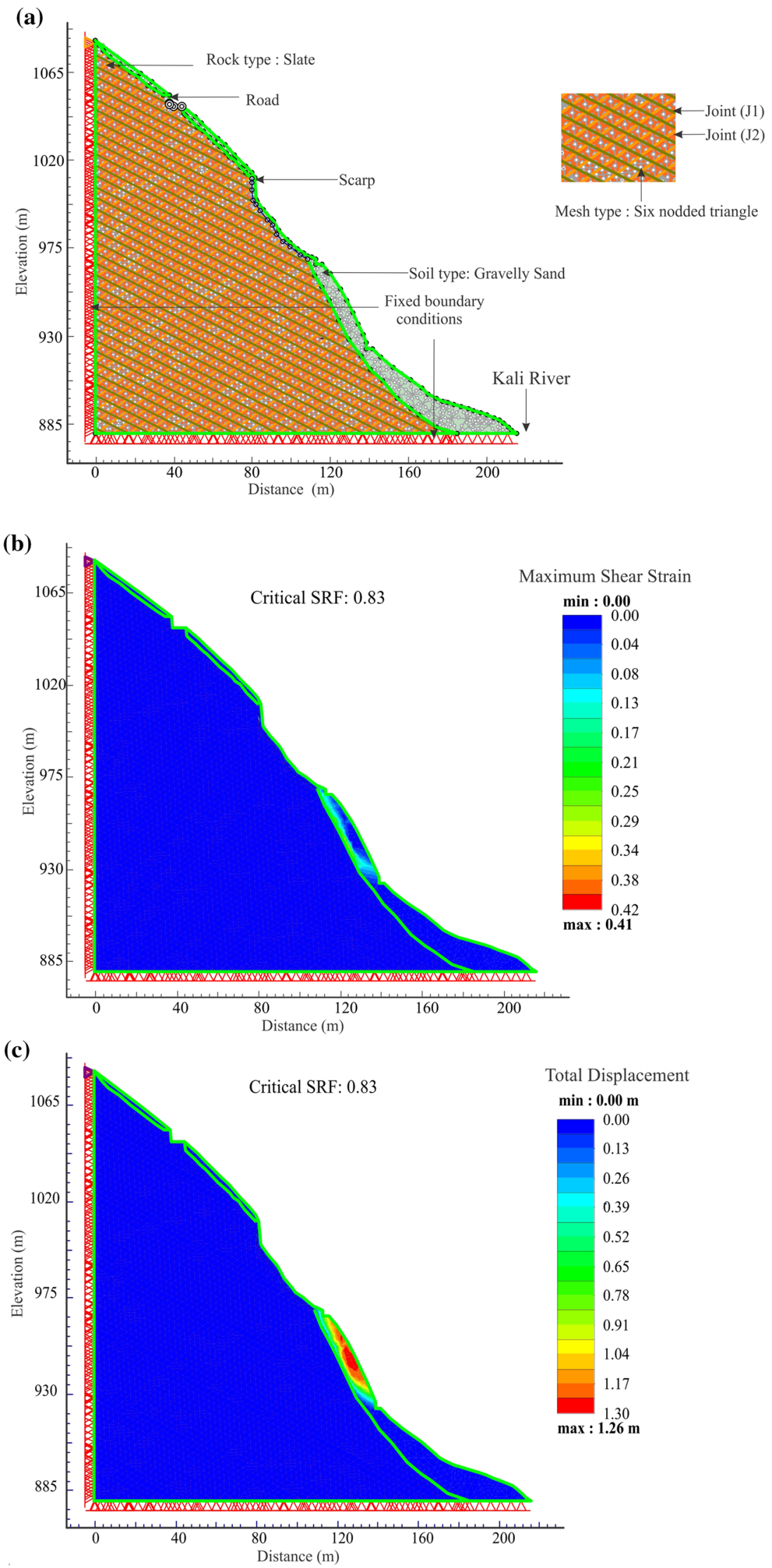

Figure 10. (a) Geometrical setting for the slope of the Khotila landslide, (b) maximum shear strain depicts higher values in the zone of detachment and (c) total displacement $(\mathrm{m})$. 
Table 1. Input parameters of the slope material properties used for the finite-element modelling.

\begin{tabular}{|c|c|c|}
\hline Material & Failure criteria & Slope material properties \\
\hline Rock type: slate & $\begin{array}{l}\text { Generalised Hoek and Brown (GHB) } \\
\text { (Hoek et al. 2002) } \\
\sigma_{1}=\sigma_{3}+\sigma_{c i}\left[m_{b}\left(\sigma_{3} / \sigma_{c i}\right)+s\right]^{\wedge} a \\
m_{b}=m_{i} \mathrm{e}^{[(\mathrm{GSI}-100) /(28)-14 D]} \\
s=\mathrm{e}^{[(\mathrm{GSI}-100) /(9-3 D)]} \\
a=\frac{1}{2}+\frac{1}{6}\left[\mathrm{e}^{\left[-\left(\frac{\mathrm{GSI}}{15}\right)\right]}-\mathrm{e}^{\left.\left[-\left(\frac{20}{3}\right)\right]\right]}\right. \\
\mathrm{GSI}=\text { Geological Strength Index } \\
\sigma_{c i}=\text { compressive strength of intact rock } \\
D=\text { disturbance factor } \\
m_{i}=\text { intact rock property }\end{array}$ & $\begin{array}{l}\text { Unit weight }\left(\mathrm{MN} / \mathrm{m}^{3}\right): 0.022 \\
\text { Young's modulus }(\mathrm{MPa}): 50000 \\
\text { Poisson ratio: } 0.15 \\
\text { UCS: } 100 \\
\text { Dilation parameter: } 0 \\
\text { mb: } 0.57 \text { (peak), } 0.48 \text { (residual) } \\
s: 0.0001 \text { (peak), } 0.0 \text { (residual) } \\
a: 0.5 \text { (peak), } 0.5 \text { (residual) } \\
D: 0\end{array}$ \\
\hline Joint & $\begin{array}{l}\text { Barton and Bandis: } \\
\text { 1. } \frac{1}{E_{\mathrm{rm}}}=\frac{1}{E_{i}}+\frac{1}{K_{n} L}(\text { Barton } 1973), \\
\text { 2. } E_{\mathrm{rm}}(\mathrm{MPa})=E_{i}\left(0.02+\frac{1-D / 2}{1+\mathrm{e}^{((60+15 D-\mathrm{GSI}) / 11)}}\right), \\
\text { Generalised Hoek and Diederichs }(2006) \\
E_{\mathrm{rm}}=\text { rock mass modulus } \\
E_{i}=\text { intact rock modulus } \\
K_{n}=\text { normal stiffness } \\
L=\text { mean joint spacing }\end{array}$ & $\begin{array}{l}\text { JCS (MPa): } 35 \\
\text { JRC: } 0.4 \text { (Barton and Choubey 1977) } \\
\text { Residual friction angle: } 30^{\circ} \text { (Barton 1973) } \\
\text { Normal stiffness (MPa/m): } 3592 \\
\text { Shear stiffness (MPa/m): } 359.2\end{array}$ \\
\hline $\begin{array}{l}\text { Soil type: gravelly } \\
\text { sand }\end{array}$ & $\begin{array}{l}\text { Mohr Coulomb } \\
\begin{array}{l}\tau=C+\sigma \text { tan } \phi, \text { where } \\
\tau=\text { shear stress } \\
C=\text { cohesion } \\
\sigma=\text { normal stress } \\
\phi=\text { angle of friction }\end{array}\end{array}$ & $\begin{array}{l}\text { Unit weight }\left(\mathrm{MN} / \mathrm{m}^{3}\right): 0.018 \\
\text { Young's modulus }(\mathrm{MPa}): 110 \\
\text { Poisson ratio: } 0.25 \\
\text { Tensile strength: } 0 \\
\text { Dilation angle (deg): } 0 \\
\text { Friction angle: } 27.4^{\circ} \text { (peak), } 27.4^{\circ} \text { (residual) } \\
\text { Cohesion }(\mathrm{MPa}): 0.03 \text { (peak), } 0.03 \text { (residual) }\end{array}$ \\
\hline
\end{tabular}

during June-September. These 4 months recorded $2164 \mathrm{~mm}$ rainfall having 493, 901, 487 and 283 $\mathrm{mm}$ rainfall during 29 days in June, 31 days in July, 27 days in August and 23 days in September, respectively (figure 5b). These 4 monsoon months received $>88 \%$ of the yearly rainfall. This concentrated rainfall in the region might have increased the pore water pressure of the slope as the material constituting the slope mainly comprises $>97 \%$ sand and silt size particles, indicating its higher permeability. The absence of any swelling clay, as indicated by the XRD analysis, further points towards the higher permeability of the slope. It has been observed that with the changing climatic pattern in the Himalayan region, many areas in the regions are experiencing heavy and concentrated rainfall in short period causing higher frequency and magnitude of landslides (Gupta et al. 2016b). During the recent past, many such kinds of landslide events have been observed from other parts of the Himalaya.
The angle of internal friction constituting the slope as observed by direct shear testing is $27.4^{\circ}$. Terzaghi et al. (1996) and Peck et al. (1974) also point that the internal friction angle is low and the density is 'very loose' for the gravelly sand. This is also indicative of the higher permeability of the slope materials. The UCS of the slope material $(42 \mathrm{kPa})$ constituting the landslide slope classifies the soil as 'soft soil'. Initially, such kind of soil accommodates a lot of water percolation, when the soil becomes saturated due to continuous rainfall after a few months, it cannot absorb abundant water and results into the failure of the slope. Further, two seasonal streams Gasku Gad and Lasku Gad, joining the Kali river near the present landslide, might have also contributed to the saturation of the landslide slope.

The Khotila landslide also lies in the close vicinity of the Dharchula Fault and the Lasku Gad Fault. The presence of these two faults has resulted in a highly weathered and fractured condition of 
the rock mass. Thus, all the geological conditions in the form of weathered and fractured rock mass, geomorphological conditions in the form of steep slope, proximity to the faults and drainage and the geotechnical characteristics of slope material constituting the slope, in the form of low UCS, grain size characteristics and high permeability towards the slope instability of the area. The conditions have been aggravated during 2016 monsoon season when the concentrated rainfall occurred leading to the slope failure.

The slope material is still lying loose on the slope and in order to predict the behaviour of slope materials in terms of estimation of deformation of the slope, i.e., total displacement and maximum shear strain, finite-element analysis of the landslide slope has been carried out by using Phase ${ }^{2}$ (version 9.0). The analysis exhibits a critical SRF of 0.83 , indicating the slope is in meta-stable condition and any change in either of geological, geomorphological, geotechnical characteristics or the environmental condition might further lead to its failure.

Further, the numerical modelling indicates the total displacement ranging between 0 and $1.26 \mathrm{~m}$ and shear strain between 0 and 0.41 . The maximum value of the shear strain and the total displacement has been noted to be observed below the zone of detachment, strongly indicating its future probability to fail.

The outcome of the present work signifies that the landslide must be monitored continuously, particularly during the rainy season and also the risk posed by this landslide must be evaluated to avoid any further loss to life and infrastructure in the region.

\section{Acknowledgements}

The authors thank the Director, Wadia Institute of Himalayan Geology, Dehradun, for all the necessary facilities and encouragement to carry out the work. Thanks are also to Dr R S Rana, Disaster Management Cell, Pithoragarh district, for discussion and providing the rainfall data.

\section{References}

Allen S K, Rastner P, Arora M, Huggel C and Stoffel M 2016 Lake outburst and debris flow disaster at Kedarnath, June 2013: Hydrometeorological triggering and topographic predisposition; Landslides 13(6) 1479-1491.
Anbalagan R, Chakraborty D and Kohli A 2008 Landslide Hazard Zonation (LHZ) mapping on meso-scale for systematic town planning in mountainous terrain; J. Sci. Ind. Res. India 67 486-497.

Anbarasu K, Sengupta A, Gupta S and Sharma S P 2010 Mechanism of activation of the Lanta Khola landslide in Sikkim Himalayas; Landslides 7(2) 135-147.

Bartarya S K and Valdiya K S 1989 Landslides and erosion in the catchment of the Gaula River, Kumaun Lesser Himalaya, India; MT Res. Dev. 9(4) 405-419.

Bartarya S K, Virdi N S and Sah M P 1996 Landslide hazards: Some case studies from the Satluj Valley, Himachal Pradesh; Him. Geol. 17(1-2) 193-207.

Barton N 1973 Review of a new shear-strength criterion for rock joints; Eng. Geol. 7(4) 287-332.

Barton N and Choubey V 1977 The shear strength of rock joints in theory and practice; Rock Mech. 10(1-2) 154.

Bist K S and Sah M P 1999 The devastating landslide of August 1998 in Ukhimath area, Rudraprayag district, Garhwal Himalaya; Curr. Sci. 76(4) 481-484.

Bisht H and Pandey D C 2016 Geo-environmental study of Kaliasaur landslide in District Rudraprayag of Garhwal Himalaya, Uttarakhand, India; Int. J. Hum. Soc. Sci. Interv. 5 7-13.

Bowles L E 1996 Foundation analysis and design (5th edn), McGraw-Hill, New York, 750p.

Cai M, Kaiser P K, Tasaka Y and Minami M 2007 Determination of residual strength parameters of jointed rock masses using the GSI system; Int. J. Rock Mech. Min. Sci. 44(2) 247-265.

Chang K T, Chiang S H and Lei F 2008 Analysing the relationship between typhoon-triggered landslides and critical rainfall conditions; Earth Surf. Proc. Land. 33(8) 12611271

Choubey V D, Chaudhari S and Litoria P K 1992 Landslide hazard zonation in Uttarkashi and Tehri Districts, UP, Himalaya, India; In: Proceeding of the landslide Glissements de terrain, sixth international symposium landslides, Christchurch, New Zealand, Balkema, Rotterdam, pp. 911-917.

Cruden D M 1991 A simple definition of a landslide; Bull. Eng. Geol. Environ. 43(1) 27-29.

Dahal R K and Hasegawa S 2008 Representative rainfall thresholds for landslides in the Nepal Himalaya; Geomorphology 100(3-4) 429-443.

Dahal R K, Hasegawa S, Yamanaka M, Dhakal S, Bhandary N P and Yatabe R 2009 Comparative analysis of contributing parameters for rainfall-triggered landslides in the Lesser Himalaya of Nepal; Environ. Geol. 58(3) $567-$ 586.

Gerrard J 1994 The landslide hazard in the Himalayas: Geological control and human action; Geomorphology 10 221-230.

Griffiths D V and Lane P A 1999 Slope stability analysis by finite elements; Geotechnique 49(3) 387-403.

Gupta V and Ahmed I 2007 Geotechnical characteristics of Surabhi Resort landslide in Mussoorie, Garhwal Himalaya, India; Him. Geol. 28(2) 21-32.

Gupta V and Bist K S 2004 The 23 September 2003 Varunavat Parvat landslide in Uttarkashi township, Uttaranchal; Curr. Sci. 87 1600-1605. 
Gupta V and Sah M P 2008 Impact of the trans-Himalayan landslide lake outburst flood (LLOF) in the Satluj catchment, Himachal Pradesh, India; Nat. Hazards 45(3) 379-390.

Gupta R P, Saha A K, Arora M K and Kumar A 1999 Landslide hazard zonation in a part of the Bhagirathi Valley. Garhwal Himalaya using integrated remote sensing-GIS; Him. Geol. 20 71-85.

Gupta V, Bhasin R K, Kaynia A M, Kumar V, Saini A S, Tandon R S and Pabst T 2016a Finite element analysis of failed slope by shear strength reduction technique: A case study for Surabhi Resort Landslide, Mussoorie township, Garhwal Himalaya; Geomat. Nat. Haz. Risk 7(5) 16771690.

Gupta V, Bhasin R K, Kaynia A M, Tandon R S and Venkateshwarlu B 2016b Landslide hazard in the Nainital township, Kumaun Himalaya, India: the case of September 2014 Balia Nala landslide; Nat. Hazards 80(2) 863877.

Hewitt K 1988 Catastrophic landslide deposits in the Karakoram Himalaya; Science 242(4875) 64-67.

Hoek E and Diederichs M S 2006 Empirical estimation of rock mass modulus; Int. J. Rock Mech. Min. Sci. 43(2) 203-215.

Hoek E, Carranza-Torres C T and Corkum B 2002 HoekBrown failure criterion (2002 edn); In: Proceedings of the fifth North American rock mechanics symposium, Toronto, Canada, Vol. 1, pp. 267-273.

Jamir I, Gupta V, Kumar V and Thong G T 2017 Evaluation of potential surface instability using finite element method in Kharsali Village, Yamuna Valley, Northwest Himalaya; J. Mount. Sci. 14(8) 1666-1676.

Kanungo D P, Pain A and Sharma S 2013 Finite element modeling approach to assess the stability of debris and rock slopes: A case study from the Indian Himalayas; Nat. Hazards 69(1) 1-24.

Kimothi S, Kumar K and Mathur S 2010 Rock mass and slope mass characterization of Kaliasaur landslide area (Uttarakhand) on National Highway-58 and correlation of results with deformation conditions; Him. Geol. 31(2) 133-143.

Kumar K and Satyal G S 1999 Cost analysis of losses caused by the Malpa landslide in Kumaun Himalaya - A basic framework for risk assessment; Curr. Sci. 77(8) 10231028.

Kumar K, Prasad P S, Kathait A and Negi I 2014 Monitoring of critical Himalayan landslides and design of preventive measures; In: Landslide Science for a Safer Geoenvironment (eds) Sassa K et al., Springer International Publishing, Switzerland, Vol. 2, pp. 583-588.

Martha T R, Roy P, Govindharaj K B, Kumar K V, Diwakar P G and Dadhwal V K 2015 Landslides triggered by the June 2013 extreme rainfall event in parts of Uttarakhand state, India; Landslides 12(1) 135146.

Matsui T and San K C 1992 Finite element slope stability analysis by shear strength reduction technique; Soils Found 32(1) 59-70.

Murthy V N S 2002 Geotechnical engineering: principles and practices of soil mechanics and foundation engineering, CRC Press, Boca Raton, 1056p.
Naithani A K, Joshi V and Prasad C 2002 Investigation on the impact of cloudburst in Tehri district, Uttaranchal31 August 2001; J. Geol. Soc. India 60(5) 573577.

Neaupane K M and Achet S H 2004 Use of back szdpropagation neural network for landslide monitoring: A case study in the higher Himalaya; Eng. Geol. 74(3-4) 213-226.

Nian T K, Chen G Q, Wan S S and Luan M T 2011 Non-convergence criterion on slope stability FE analysis by strength reduction method; J. Convergence Info. Tech. 6(5) 78-88.

Owen L A, Kamp U, Khattak G A, Harp E L, Keefer D K and Bauer M A 2008 Landslides triggered by the 8 October 2005 Kashmir earthquake; Geomorphology 94(1-2) $1-9$.

Pachauri A K and Pant M 1992 Landslide hazard mapping based on geological attributes; Eng. Geol. 32(1-2) 81100.

Panikkar S V and Subramanyan V 1996 A geomorphic evaluation of the landslides around Dehradun and Mussoorie, Uttar Pradesh, India; Geomorphology 15(2) 169 181.

Pant P D and Khayingshing L 2005 Amiya landslide in the catchment of Gaula River, southern Kumaun, Uttaranchal; J. Geol. Soc. Ind. 65(3) 291-295.

Paul S K 1985 Structural and petrological studies of Munsiari Dharchula area, Great Himalaya in Kumaun; PhD Thesis, Kumaun University, Nainital, unpublished dissertation.

Paul S K, Bartarya S K, Rautela P and Mahajan A K 2000 Catastrophic mass movement of 1998 monsoons at Malpa in Kali Valley, Kumaun Himalaya (India); Geomorphology 35(3-4) 169-180.

Peck R B, Hanson W E and Thornburn T H 1974 Foundation Engineering; Vol. 10, Wiley, New York.

Rautela P and Thakur VC 1999 Landslide hazard zonation in Kaliganga and Madhyamahshwar valleys of Garhwal Himalaya: A GIS based approach; Him. Geol. 20(2) 31-44.

Roscoe K H 1970 The influence of strains in soil mechanics; Geotechnique 20(2) 129-170.

Sah M P and Mazari R K 1998 Anthropogenically accelerated mass movement, Kulu Valley, Himachal Pradesh, India; Geomorphology 26(1-3) 123-138.

Sah M P, Asthana A K L and Rawat B S 2003 Cloud burst of August 10, 2002 and related landslides and debris flows around Budha Kedar (Thati Kathur) in Balganga valley, district Tehri; Him. Geol. 24(2) 87-101.

Saha A K, Gupta R P and Arora M K 2002 GIS-based landslide hazard zonation in the Bhagirathi (Ganga) valley, Himalayas; Int. J. Remote Sens. 23(2) 357-369.

Sarkar S, Kanungo D P and Chauhan P K S 2011 Varunavat landslide disaster in Uttarkashi, Garhwal Himalaya, India; Quat. J. Eng. Geol. Hydrogeol. 44(1) 17-22.

Sati S P, Naithani A and Rawat G S 1998 Landslides in the Garhwal Lesser Himalaya, UP, India; Environmentalist 18(3) 149-155.

Sharma S K and Singh S 2013 Landslide monitoring in the Himalayan region, India; In: Landslide science and practice, Springer, Berlin, Heidelberg, pp. 99-103. 
Standard-IS, Indian. 2720 (Part 4) 1985 Method of test for soils, grain size analysis - Mechanical method; New Delhi, India.

Standard-IS, Indian. 2720 (Part 5) 1985 Methods of test for soils, determination of liquid and plastic limit of soils; New Delhi, India.

Standard-IS, Indian. 2720 (Part 13) 1986 Method of test for soils, direct shear test. New Delhi, India.

Standard-IS: 2720 (Part 10) 1991 Method of test for soils: Unconfined compressive strength; New Delhi, India.

Standard-IS: 1498-1970 (Reaffirmed) 2007 Classification and identification of soils for general engineering purposes; New Delhi, India.

Talobre J A 1967 Rock mechanics and its application; Dunod, Paris, 442p (in French).

Corresponding editor: N V Chalapathi RaO
Terzaghi K, Peck R B and Mesri G 1996 Soil mechanics in engineering practice; John Wiley \& Sons, New York.

Valdiya K S 1980 Geology of Kumaun Lesser Himalaya; Wadia Institute of Himalayan Geology, Dehradun, UP, 291p.

Wang S, Fu B and Li Z (eds) 2001 Frontiers of rock mechanics and sustainable development in the 21st century; In: Proceedings of the 2001 ISRM international symposium, 2nd Asian rock mechanics symposium (ISRM 2001-2nd ARMS), 11-14 September 2001, AA Balkema, Beijing, China.

Zienkiewicz O C, Humpheson C and Lewis R W 1977 Discussion: Associated and non-associated visco-plasticity and plasticity in soil mechanics; Geotechnique 27(1) 101102. 